\title{
Contribution of Small and Medium Enterprises Run by Women in Generating Employment Opportunity in Rwanda
}

\author{
Rachel Bayisenge ${ }^{1}$, Hu Shengede ${ }^{1}$, Yves Harimana ${ }^{2}$, Jean Bosco Karega ${ }^{3}$, Margret Lukileni ${ }^{4}$, Muhammad \\ Nasrullah $^{1}, \mathrm{Hu}$ Xinrui $^{1}$ \& Beneyo Emmerance Nteziyaremye ${ }^{5}$ \\ ${ }^{1}$ School of Economics and Management, Northeast Agricultural University, Harbin, China \\ ${ }^{2}$ School of Food Science, Northeast Agricultural University, Harbin, China \\ ${ }^{3}$ School of Business and Economics, University of Rwanda, Kigali, Rwanda \\ ${ }^{4}$ Oshikango, Namibia \\ ${ }^{5}$ School of Environmental Sciences and Technology, Dalian University of Technology, Dalian, China. \\ Correspondence: Prof. Hu Shengede, School of Economics and Management, Northeast Agricultural University, \\ Harbin, Heilongjiang, No. 600 Chngjiang Road, China. E-mail: 78172977@qq.com, \\ bayisengerachel@yahoo.com
}

Received: November 20, 2019

Accepted: January 25, 2020

Online Published: February 15, 2020

doi:10.5539/ijbm.v15n3p14

URL: https://doi.org/10.5539/ijbm.v15n3p14

\begin{abstract}
Small and Medium Enterprises are the key to the national economic development as a way to improve its population livelihood. The main reason for this sector is a potential employment with the low cost of the capital. The contribution of small and medium enterprises run by women in society was recognized to the employment generation, gender equality and economic development. A personnel initiative, vision, and innovation to grow their businesses are well needed. In this research 15 districts out of 30 were selected to get all needed data, and thirteen (13) women were communicated in each selected district (15) as a sum of a hundred and ninety-five (195) correspondents. The combination of quantitative and qualitative methods was used to analyze data, and questionnaires and interviews were used to collect data. Our results have been proved that small and medium enterprises run by women and sustainability of Rwandan economic development were closely related as the SMEs run by women increase and employment opportunities also increase. It was noted that women owned SMEs is a central driving effort behind gender equality, poverty reduction, and job creation. Therefore, it is recommended that the government might set the policy to encourage women in doing business whereby women in different regions of Rwanda should be given enough attention in economy activities through both small and medium enterprises, and entrepreneurship.
\end{abstract}

Keywords: small and medium enterprises, women, employment generation, gender equality

\section{Introduction}

The contribution of Small and Medium Enterprises (SMEs) is one of the engines of national economic growth, and job creation to the nation's development in worldwide(Tambunan, 2008). Many countries are using Small and Medium Enterprises for modernization, industrialization, achievement, and clear significant in employment opportunities, which is adorable by the citizens(Aremu \& Adeyemi, 2011). In the most industrial countries, $98 \%$ up of all tools firm come from SMEs (Note 1), and show up the main sources of employment(Kira \& He, 2012), In addition, the SMEs sector is contributing to more than $22 \%$ of the labor force as productive in developing countries (Dalitso \& Peter, 2000). The level of gender equality in the labor force is still low, which is a disadvantage to women-owned SMEs compared to men especially in financial means(Marlow \& Patton, 2005). In case of economic development; the untapped possible of updated women-owned SMEs intends that employment and firms should be successful if businesses to both genders have equal opportunities (Löfström, 2009).

In Rwanda, Small and Medium Enterprises (SMEs) and cooperatives are top drivers to the employment generations and economic growth. In 1994, Rwanda genocide has paralyzed the production sector and most population engaged in agricultural sector up to now, where $70 \%$ are working in this sector, and apart from it the other economic sectors were extremely affected too, especially to Small and Medium Enterprises(Francis;, 2019). 
So far, SMEs are a crucial role in the employment generation and economy development of the country, where the Rwandan population estimated to be more than 12 million, and its land (arable) was seemly infertile and unproductive(Worldometer, 2019). In Rwanda, women are vital to social-economic transformation, and it can happen in different ways; either in leadership or in business (Vis, 2012). The statistics given by the Ministry of Trade and Industry showed that $98 \%$ of the all nations business are SMEs, it's present $41 \%$ compare to all private jobs(Mutandwa, Taremwa, \& Tubanambazi, 2015). In fact, the government of Rwanda has created a favorable environment to increase SMEs like the online speed formal business registration just within 4 hours, high level of investors protection, online payments, good infrastructure, access to the energy, and educated workforce without corruption to one way of having a serious and smart economy development(LEEDOM, 2016). In addition, the contribution of women after genocide until now in rebuilding and rehabilitating the country is not negligible, where most of the men were killed in most families, women found themselves widowed in taking care of their own and their families in that hard time, it was not easy, and the only way to generate the stainable income was creating small or medium enterprise (SMEs) to cover their needs and their families as well, this presented a clear employment generation and economic development of Rwanda.

The main objective of this research is to assess the contribution of small and medium enterprises (SMEs) run by women in generating employment opportunities in Rwanda. If SMEs run by women in Rwanda restructured to contribute to employment generation and gender equality will improve the national development as well as poverty reduction, hunger, and other human needs. And the Researcher is more interested in women empowerment through various fields; either Business or agricultural management, that's how the research topic allowed by the present scholarship to be accomplished. Thus, the study outcome will contribute to job creation, gender equality, and go to long way in protecting a reversal of SMEs run by women.

\section{Materials and Methods}

The study used quantitative and qualitative methods with the selected analysis strategy in the study. The analyzed data were gathered from primary and secondary sources. The research work used the interview to gather information from the respondents and the observation methods(Seawright \& Gerring, 2008). The targeted people were women entrepreneurs as our dependents in the whole country of Rwanda. The message needed was from SMEs run by women and interpreted their contribution to employment generation in the development of Rwanda.

The researcher selected randomly 15 districts out of 30 in the whole country namely: Gatsibo, Ngoma, Rwamagana, Gasabo, Kicukiro, Nyarugenge, Gicumbi, Musanze, Rulindo, Huye, Nyanza, Nyaruguru, Ngororero, Nyamasheke, Rubavu with a survey of 396 SMEs run by women. The formula of Cochran 3rd Edition was used to determine our quantitative data with the aid of the SPSS computer program(Cochran, 1977). The below was the Cochran ( $3^{\text {rd }}$ Edition $)$ formula used by a researcher to determine her sample size:

As the registered number of SMEs run by women were low, we took the below formula for infinite unregistered ones;

$$
\text { a) } S=Z^{2^{*}} \mathbf{P}^{*}(\mathbf{1}-\mathbf{P}) / \boldsymbol{m}^{2}
$$

S: sample size for infinite population

Z: Z-score (confidence level; 95\%=1.960) (Note 2)

P: population proportion (assumed to be $50 \%=0.5$ )

m: margin of error $(5 \%=0.05)$ (Note 3$)$

$$
\begin{aligned}
& \boldsymbol{S}=\mathrm{Z}^{2 *} \mathrm{P}^{*}(1-\mathrm{P}) / m^{2} \\
& \boldsymbol{S}=\left(\mathrm{Z}-\mathrm{score}^{2 *} \mathrm{P}^{*}(1-\mathrm{P}) /(\text { margin of error })^{2}\right. \\
& \boldsymbol{S}=(1.96)^{2 *} 0.5^{*}(1-0.5) /(0.05)^{2} \\
& \boldsymbol{S}=3.8416^{*} 0.25 / 0.0025 \\
& \boldsymbol{S}=384.16
\end{aligned}
$$

Then, the sample size for the infinite population is $\mathbf{3 8 4 . 1 6}$ (Note 4)

\section{We must adjust it to the population (women) as our respondents.}

Adjusted the sample size to 396 populations (women);

We used the following formula to adjust our sample size;

$$
\text { b) Adjusted sample size }=(S) / 1+[(S-1) / \text { population }]
$$




$$
\begin{aligned}
& \text { Adjusted } S=(S) / 1+[(S-1) / \text { population }] \\
& \text { Adjusted } S=(384.16) / 1+[(384.16-1) / 396] \\
& \text { Adjusted } S=(384.16) / 1.9675757575757 \\
& \text { Adjusted } S=195.245 \simeq 195
\end{aligned}
$$

The sample size from 396 SMEs run by women in Rwanda is 1954 (Note 5).

Thirteen (13) women-owned SMEs were communicated in every selected district (15) sum of one hundred and ninety-five (195) sample sizes. In the selection of respondents, we used a simple random sample and properly purposive sampling technique to our dependents respondents who had the same opportunity to the selected areas. Both systems; observation and interview were also used to receive more details from our respondents. During the collection of the data, we committed more women who were busy and don't have time to read questionnaires, that caused us to apply more interview system. The closed and open-ended questions were used. The direct scrutiny was used by the researcher in an evaluation procedure to receive more understandings and represent their answers with proved given reports. The researcher has edited all collected data with regularity of them. And, all information was grouped and summarized well mathematically.

The described statistics were used to determine our quantitative data with a help of SPSS software, the figures and tables were used in the interpretation of collected data, and the researcher has been described and discussed them according to the received information.

\section{Results and Discussions}

Small, Micro and Medium Enterprises present $95 \%$ of all firms, 55\% of GDP, $60-70 \%$ of employment as the majority of the new jobs to many countries(Etuk, Etuk, \& Michael, 2014). Rwanda has 186822 businesses and $99.7 \%$ of them are small and medium Enterprises (SMEs), the employment in business by sex present is $62 \%$ of male and 38\% of female(MURANGWA, 2017), which is still low compared to women size in the entire country.

Business or entrepreneurship was not a Rwandan culture; the majority of people depended on agriculture, women were the housewives, and the entrepreneurship at the first place was for foreigners. After that, Rwandan males started also to do it, and women didn't dare it because of the culture, in that time all money (cash) belonged to men as the heads of the families. After the genocide of 1994, most of the women became widowers and found themselves as the head of the households; they had to take care of themselves, their children and orphans from different families. Most of these women were not educated to seek jobs, and they started to think how they were able to create jobs, and began to look around them and recalled what their husbands were used to do before being killed in Genocide against Tutsi, and they cooperated with few men who were around them and try to do the same things in different business and being the problems solvers of their families, that was how most of the women became entrepreneurs in Rwanda. So far, Women are playing a significant role to their country development, where $42 \%$ of all enterprises lead by women and count $30 \%$ of the GDP and this has reduced unemployment rate inside the country(Corporation, 2008).

The aim of this research is to assess the contribution of SMEs run by women in generating employment opportunity and gender equality in Rwanda. The researcher has selected 15 districts out of 30 randomly to get all needed data from field. Thirteen (13) women were communicated in every selected district (15) as a sum of one hundred and ninety-five (195) of our sample size. 
Table 1. Occupation of the respondents

\begin{tabular}{|c|c|c|c|c|c|c|c|c|c|c|c|c|}
\hline \multirow{3}{*}{ Selected Districts } & \multirow{3}{*}{$\begin{array}{l}\text { ICT } \\
\text { Software }\end{array}$} & \multicolumn{11}{|c|}{ Occupation of the respondents } \\
\hline & & Decoration & Pharmaceuticals & Trade & Shops & Handcrafts & Fashion/Design & Restaurants & Industries & Cut & Frequency & $\%$ \\
\hline & & & & & & & & & & Flower & & \\
\hline Gatsibo & 0 & 1 & 1 & 1 & 2 & 3 & 0 & 2 & 1 & 2 & 13 & 6.66 \\
\hline Ngororero & 0 & 2 & 1 & 3 & 3 & 2 & 0 & 1 & 0 & 1 & 13 & 6.66 \\
\hline Ngoma & 0 & 1 & 1 & 2 & 3 & 2 & 0 & 1 & 2 & 1 & 13 & 6.66 \\
\hline Rwamagana & 0 & 2 & 2 & 2 & 2 & 3 & 0 & 1 & 0 & 1 & 13 & 6.66 \\
\hline Gasabo & 1 & 2 & 1 & 1 & 0 & 2 & 2 & 1 & 2 & 1 & 13 & 6.66 \\
\hline Kicukiro & 1 & 1 & 0 & 0 & 1 & 3 & 1 & 1 & 4 & 1 & 13 & 6.66 \\
\hline Nyarugenge & 0 & 1 & 1 & 3 & 1 & 2 & 2 & 1 & 1 & 1 & 13 & 6.66 \\
\hline Gicumbi & 1 & 1 & 0 & 0 & 2 & 4 & 0 & 3 & 1 & 1 & 13 & 6.66 \\
\hline Musanze & 2 & 0 & 3 & 0 & 2 & 2 & 0 & 2 & 1 & 1 & 13 & 6.66 \\
\hline Rulindo & 0 & 4 & 2 & 1 & 2 & 2 & 0 & 1 & 0 & 1 & 13 & 6.66 \\
\hline Huye & 1 & 4 & 1 & 0 & 3 & 3 & 0 & 1 & 0 & 0 & 13 & 6.66 \\
\hline Rubavu & 1 & 1 & 2 & 0 & 4 & 2 & 0 & 2 & 0 & 1 & 13 & 6.66 \\
\hline Nyanza & 1 & 3 & 1 & 1 & 2 & 2 & 0 & 1 & 1 & 1 & 13 & 6.66 \\
\hline Nyamasheke & 0 & 2 & 1 & 1 & 5 & 2 & 0 & 1 & 1 & 0 & 13 & 6.66 \\
\hline Ruhango & 1 & 3 & 2 & 1 & 3 & 2 & 0 & 1 & 0 & 0 & 13 & 6.66 \\
\hline Total & 9 & 28 & 19 & 16 & 35 & 36 & 5 & 20 & 14 & 13 & 195 & $100 \%(99.9 \%)$ \\
\hline
\end{tabular}

Source: Authors' field survey, 2019.

Table 1 presents 15 selected districts and 13 SMEs run by women in every selected district. Occupations of women from selected area were: ICT Software, Decoration, Pharmaceuticals, Trade, Shops, Handcrafts, Industries, Fashion/Design, Restaurants, and Cut Flowers. It should be emphasized that the majority of communicated women were in handcrafts and shop sectors. We found that Kicukiro district hold the biggest number of women in the industrial sector compared to other districts (4). According to Jeanne IZABILIZA, Rwanda has an ambition of promoting gender equality and empowering its women to sustain the needed peace and development of the country (Izabiliza, 2003). In Rwanda, women are empowering through different sectors, and the researcher picked SMEs as one of them to assess their contribution in generating employment opportunities.

Table 2. Education level of respondents

\begin{tabular}{|c|c|c|c|c|c|c|c|c|}
\hline $\begin{array}{l}\text { Occupation and } \\
\text { Education level of the } \\
\text { respondents }\end{array}$ & Masters & Bachelor & Secondary & Primary & Technical & Uneducated & Frequency & $\begin{array}{l}\text { Percentage } \\
(100 \%)\end{array}$ \\
\hline ICT Software & 0 & 5 & 4 & 0 & 0 & 0 & 9 & 4.6 \\
\hline Decoration & 0 & 2 & 6 & 7 & 7 & 6 & 28 & 14.4 \\
\hline Pharmaceuticals & 9 & 10 & 0 & 0 & 0 & 0 & 19 & 9.74 \\
\hline Trade & 0 & 0 & 3 & 8 & 3 & 2 & 16 & 8.2 \\
\hline Shops & 3 & 3 & 10 & 11 & 1 & 7 & 35 & 17.94 \\
\hline Handcrafts & 0 & 0 & 7 & 14 & 6 & 9 & 36 & 18.46 \\
\hline Fashion/Design & 1 & 3 & 1 & 0 & 0 & 0 & 5 & 2.56 \\
\hline Restaurants & 2 & 2 & 5 & 2 & 1 & 8 & 20 & 10.26 \\
\hline Industries & 5 & 7 & 2 & 0 & 0 & 0 & 14 & 7.18 \\
\hline Cut Flowers & 0 & 1 & 5 & 1 & 3 & 3 & 13 & 6.66 \\
\hline Total & 20 & 42 & 47 & 43 & 17 & 26 & 195 & 100 \\
\hline
\end{tabular}

Source: Authors' field survey, 2019.

The majority of women finished; Secondary, primary, and bachelor respectively $(42,47,43)$, only 20 women hold master's degrees among 195 communicated. 17 women hold the technical certificates and 26 were uneducated. This marginal different suggests that females in Rwanda could performed well in the past years where the culture limited them to attend schools. Allison \& Shirley observed that gender equality in education 
should be improved especially to females' performance and outcomes that will be a key to the country development plans, and protect also women through human rights.(Huggins \& Randell, 2007)

Due to communicated women, we found that some of them were using the distance courses to get their degree/certificates and others were attending evening programs to the different schools within the country then combined them with their daily activities to take care themselves and their households. We have found other groups of women who learned simple reading and writing through their churches and cooperatives' organizations. We found that educated women had better management skills than uneducated ones. The findings suggest that it could be better to implement the environmental policies that will help females to reduce barriers that are limiting them to perform well either in business or at school.

3.1 Employment Generated by SMEs Run by Women between Years 2014-2018

Table 3. Recruited employees

\begin{tabular}{|c|c|c|c|c|c|c|c|c|c|c|c|c|}
\hline \multirow{2}{*}{$\begin{array}{l}\text { Recruited } \\
\text { Employees } \\
\text { year 2014- }\end{array}$} & \multirow[b]{2}{*}{$\begin{array}{l}\text { between } \\
2018\end{array}$} & \multicolumn{11}{|c|}{ Selected SMEs run by Women } \\
\hline & & $\begin{array}{l}\text { ICT } \\
\text { software } \\
(9) \\
\end{array}$ & $\begin{array}{l}\text { Decoratio } \\
\mathrm{n}(28)\end{array}$ & $\begin{array}{l}\text { Pharmaceu } \\
\text { tical (19) }\end{array}$ & $\begin{array}{l}\text { Trade } \\
(16)\end{array}$ & $\begin{array}{l}\text { Shops } \\
(35)\end{array}$ & $\begin{array}{l}\text { Hander } \\
\text { afts (36) }\end{array}$ & $\begin{array}{l}\text { Fashion/d } \\
\text { esign(5) }\end{array}$ & $\begin{array}{l}\text { Restaur } \\
\text { ants(20) }\end{array}$ & $\begin{array}{l}\text { Industri } \\
\text { es (14) }\end{array}$ & $\begin{array}{l}\text { Cut } \\
\text { flower } \\
\mathrm{s}(13) \\
\end{array}$ & Total \\
\hline \multirow{3}{*}{2014} & $\begin{array}{l}\text { Between } \\
1-5\end{array}$ & 7 & 16 & 19 & 13 & 33 & 0 & 4 & 11 & 1 & 13) & \\
\hline & $\begin{array}{l}\text { Between } \\
6-10\end{array}$ & 2 & 9 & 0 & 3 & 2 & 4 & 1 & 9 & 2 & 0 & 195 \\
\hline & $\begin{array}{l}11 \text { and } \\
\text { Above }\end{array}$ & 0 & 3 & 0 & 0 & 0 & 32 & 0 & 0 & 11 & 0 & \\
\hline \multirow[t]{2}{*}{2015} & $\begin{array}{l}\text { Between } \\
1-5\end{array}$ & 8 & 16 & 19 & 12 & 32 & 1 & 4 & 9 & 1 & $13^{-}$ & \\
\hline & $\begin{array}{l}\text { Between } \\
6-10\end{array}$ & 1 & 9 & 0 & 4 & 3 & 2 & 1 & 11 & 1 & 0 & 195 \\
\hline \multirow{4}{*}{2016} & $\begin{array}{l}\text { Between } \\
6-10\end{array}$ & 0 & 3 & 0 & 0 & 0 & 32 & 0 & 0 & 12 & 0 & \\
\hline & $\begin{array}{l}\text { Between } \\
1-5\end{array}$ & 8 & 13 & 18 & 13 & 32 & 1 & 3 & 10 & 1 & $13^{\circ}$ & \\
\hline & $\begin{array}{l}\text { Between } \\
6-10\end{array}$ & 1 & 10 & 1 & 2 & 3 & 3 & 1 & 10 & 1 & 0 & 195 \\
\hline & $\begin{array}{l}11 \text { and } \\
\text { Above }\end{array}$ & 0 & 5 & 0 & 1 & 0 & 32 & 1 & 0 & 12 & 0 & \\
\hline \multirow[t]{2}{*}{2017} & $\begin{array}{l}\text { Between } \\
1-5\end{array}$ & 8 & 8 & 18 & 11 & 34 & 1 & 3 & 11 & 1 & 137 & \\
\hline & $\begin{array}{l}\text { Between } \\
6-10\end{array}$ & 1 & 16 & 1 & 4 & 4 & 3 & 1 & 9 & 1 & 0 & 195 \\
\hline \multirow{4}{*}{2018} & $\begin{array}{l}11 \text { and } \\
\text { Above }\end{array}$ & 0 & 6 & 0 & 1 & 0 & 32 & 1 & 0 & 12 & 0 & \\
\hline & $\begin{array}{l}\text { Between } \\
1-5\end{array}$ & 8 & 7 & 18 & 12 & 31 & 1 & 2 & 11 & 1 & 13 & \\
\hline & $\begin{array}{l}\text { Between } \\
6-10\end{array}$ & 1 & 15 & 1 & 3 & 3 & 1 & 2 & 9 & 0 & 0 & 195 \\
\hline & $\begin{array}{l}11 \text { and } \\
\text { Above }\end{array}$ & 0 & 6 & 0 & 1 & 1 & 34 & 1 & 0 & 13 & 0 & \\
\hline
\end{tabular}

Source: Authors' field survey, 2019.

Table 3 presents our selected SMEs run by women and how they are contributing in generating employment opportunity in Rwanda;

\subsubsection{ICT Software}

Due to table 3; the data found that the level of females in ICT was still low. 9 communicated women were recruited 1 to 5 employees. The study discovered that the value of ICT to women businesses skills will be good 
in coming days as long as they will keep improving, and it suggests that women should be encouraged and think wisely on how ICT could be improved to their daily works. For the young ladies who are still at schools can improve their skills in ICT through MsGeek competition program which has a purpose of proving young women and girls who are competent in technology(MURANGWA, 2017).

Moreover, one of the Rwandans young women who works as an entrepreneur, she is also a founder managing director of Shaking Sun called Akaliza Keza Gara, just in short of period, she has been accomplished more in technology field, and this should be an encouraging example to other women who want to join ICT sector (Twahirwa, 2014). Even the sector has low number of females compare to males, it is contributing also as one of the SMEs run by women in generating employment opportunity to Rwandans.

\subsubsection{Decoration}

The sector has more women and the researcher has picked only 28 women in 15 selected districts. From 2014 to 2015 the recruited number has been increased, and the majority of them were between 1 to 5 employees. In 2016 and above; the quantity was decreasing as the table 3 shown. Based to wedding ceremonies in Rwanda, decoration sector has been improved, and the big number of grooms and brides are renting materials and places to use in their celebration parties which are creating more jobs to people. Men and women are doing these kinds of businesses to increase their incomes, which are contributing also in generating employment opportunity to the owner and others.

\subsubsection{Pharmaceutical}

The sector has 19 selected women from the field, and the results represent that since 2014 to 2015 the majority of communicated women were recruiting 1 to 5 employees (see Table 3). From 2016 to 2018 we found a woman who was empowered and was able to open her second pharmacy in Nyanza district which was created another opportunity in employment that's how she was able to recruit more than 5 employees as shown in table 3 . The data found that the most number of pharmacies were in the cities, and it suggests that it could be better if the number of pharmacies will be increased to rural areas, which may be increase the level of job opportunities to them as well.

\subsubsection{Trade}

According to table 3 , the study identified the value of women through trade sector and most of the respondents were recruited between 1 to 10 employees. From 2017 to 2018, the recruitment increased and reduced in 2016 . The year 2017 to 2018 was improved again based on collected data.

Therefore, SMEs in Rwanda eager to use a convenient way of digital markets and some of the respondents were already using it; like mobile money in selling credits, and transfer money which were creating jobs in other side. Some of them were doing the online business and others had their website, "Murukali.com" was one of them, during the interview she (the owner) said that they had 12 workers including 5 males and 7 females(Hussain, 2013), which means that they are creating jobs obviously.

Moreover, the government of Rwanda has provided a supplementary service between businessmen and citizens via e-government portals, we can mention one of them called "Irembo", but the big numbers of people were still using cash transactions in payment. We found other groups of women who used to buy milk from the farmers and bring them to dairy stations, and this kind of trade were required low capital compare to others. Due to these all trade made by women; the research discovered that they are contributing in employment generation through them even though the sector still has a clear gap for females.

\subsubsection{Shops}

Table 3 presents data from selected shops in Rwanda, and most of them were worked together with their family members, in this kind of sector, the recruited employees from outside were very few except to some supermarkets which were able to employ more than 6 people depends on clients they had. From received data, it suggests that if women can be able to open more supermarkets or more shops in different places and forget about their past culture which thought them that all kinds of cash/money belonged to men (husbands) and be able to keep themselves forward in business; the unemployment rate will be decrease and more Rwandan women will be empowered economically and this will contribute to gender equality as well.

\subsubsection{Handcrafts}

Due to table 3; the sector of handcrafts has a big number of women compare to others in this research study, and we discovered that the sector recruited more than 11 employees; it supported them significantly and most of them were able to solve the problems of their households. Handcrafts had been globally renewable with a clear 
contribution in generating employment opportunity, as an example of Rwanda, it is through the local artisans as AGASEKE, and other jewelry products (bracelets, necklaces, bangles) (Reporter, 2011). These country tradition handcrafts currently are giving jobs to more women than other sectors.

The researcher has identified the value of AGASEKE and tried to contact one of them named Gahaya links which is also a Rwandan handcraft company and it was working with more than 4000 employees (weavers), the most of them worked in groups as cooperatives, and this kind of groups or cooperatives are assisting a lot to national unity, reconciliation even to job creation.

Due to its beneficiaries, it should be better to get all needed supports from inside or outside of the country like marketing, trainings, access to finance, and improve more their capacity, which will give the access to create more jobs to people.

\subsubsection{Fashion/Design}

Fashion and design were started years ago in Rwanda; Table 3 has shown that from 2014 to 2015 the recruited people were between 1to 5, and in 2016 to up be increased. The data confirmed that fashion and design recruited few people compared to other selected SMEs run by women from study area. So far, the sector is growing with its designers. The government has started "Made in Rwanda" which is promoting the local products, and the following are some available examples of it; Inzuki designs, Sonia Mugabo (SM), Haute Baso and Uzi collection,... (MANDEYA, 2019).

The detected sector is giving the country insights to the future point in economy development and this will boost employment opportunities to many people especially to the designers. In additional, as long as this sector improves, it will be great impact to Africa or Rwanda industries which based on culture, and become other opportunity to the employment and economy development as well. It suggests that could be more successful if the country supports the sector for its own bright future.

\subsubsection{Restaurants}

Table 3 presents 20 restaurants run by women from selected SMEs. We found that most of them recruited between 1 to 10 employees, the data confirmed that restaurants do not need more employees except their special events. Women were better than men in this business especially when it comes to the kitchen stuffs. It suggests that if women are financially supported, they will be able to open more restaurants, and get more benefits from them including creation of more job opportunities.

\subsubsection{Industries}

According to table 3, industries recruited a significance number of employees. The data confirmed that when industries increase inside the country, it will create more jobs to Rwandans and foreigners. We can mention some of them led by women such as UPCOT, CEZA Suppliers, Zirakamwa Meza Nyanza Diary, Agasaro Organic farming, NBG, Dokmai Rwanda, candle making (Nice dreams). It suggests that the more women industries increase, the more job opportunities increase even gender equality will be promoted and boost the country economy development as well.

\subsubsection{Cut Flowers}

13 women from cut flowers sector have been communicated. We found that all of them recruited 1 to 5 employees due to the status of their businesses. It discovered that some of them used to buy flowers from big industries and open small shops to sell them, others used to cultivate them on the small land they have around and sell them to people. As the National Agriculture Export Board (NAEB) said that Rwanda has a lack of investors in flower industries sector, which is one of the barriers the sector has(Lacs, 2015). It suggests that if the investors could be increased in it, then the citizens will get benefits from it (employment) and the country economy will be growth through exportation and domestic market.

Based to the above perspectives, women are contributing positively in generating employment opportunity, gender equality and country development through different SMEs they are doing as we have seen from the previous explanations (see Table 3), and it is encouraging the rest of women to fearless and starts thinking on how they can invest in business. Due to the selected SMEs run by women, the data has been proved their great impacts to Rwandans welfare, country economy and job creations. Besides that, gender equality in all sectors should be emphasized in a way of empowering women as a big number of the population, and avoid the ignorance of powers from them as it used to be years ago in Rwandan culture by giving both sexes the same opportunities, which will lead the country to its goals of development(Benería, Berik, \& Floro, 2015). 
3.220 Businesswomen Who Are Encouraging Others in Business and Their Contribution in Generating Employment Opportunity in Rwanda

Table 4. 20 businesswomen

\begin{tabular}{|c|c|c|c|}
\hline $\mathbf{S} / \mathbf{N}$ & 20 businesswomen & SMEs run by 20 businesswomen & Employees \\
\hline 1 & Joy Ndungutse \& & Gahaya Links & 4000 \\
\hline 2 & Janet Nkubana & & \\
\hline 3 & Lydie Hakizimana & Drakkar Limited & 75 \\
\hline 4 & Sonia Mugabo & Sonia Mugabo (SM)“Fashion Brand" & 19 \\
\hline 5 & Bernadette Umunyana & Dokmai Rwanda & 9 \\
\hline 6 & Ysolde Shimwe \& & & 17 \\
\hline 7 & Kevine Kagirimpundu & UZURI K\&Y & \\
\hline 8 & Linda Mukangoga \& & haute | baso & 76 \\
\hline 9 & Candy Basomingera & & \\
\hline 10 & Teta Isibo & Inzuki Designs & 200 \\
\hline 11 & Gloria Kamanzi Uwizera & Glo Creations & 12 \\
\hline 12 & Natacha Nduwimana & Jelim Pemier Events & 16 \\
\hline 13 & Sandra Idossou & The serviceMag & 6 \\
\hline 14 & Mireille Karera & KORA Associates & \\
\hline 15 & Denise Umunyana \& & Right Seat & 2 \\
\hline 16 & Celine Uwineza & & \\
\hline 17 & Carine Zoe Umutoni & Onyx & 10 \\
\hline 18 & Christelle Kwizera & Water Access Rwanda (WARwanda) & 51 \\
\hline 19 & Mary Miner \& & & 2 \\
\hline \multirow[t]{2}{*}{20} & Kate Woska & Atikus Investments Incorporated & \\
\hline & Total & & 4495 \\
\hline
\end{tabular}

Source: Authors' field survey, 2019.

Table. 4 represents 20 businesswomen who are encouraging others in Rwanda business sector. We found that the majority of recruited employees were from Gahaya links with 4000 wavers. These 20 businesswomen were able to create 4495 jobs, which means that if women could be unafraid to invest in industries, the rate of employment generation will be increased, which will contribute also to gender equality and country economy development.

\subsection{External and Internal Factors Are Affecting SMEs Run by Women}

Table 5. External and internal factors are affecting SMEs run by women

\begin{tabular}{|c|c|c|c|c|c|c|c|c|c|c|c|c|}
\hline External and internal & Selected & Es run by & omen (195) & 15 dis & & & & & & & & \\
\hline $\begin{array}{l}\text { factors are affecting } \\
\text { SMEs run by women }\end{array}$ & $\begin{array}{l}\text { ICT } \\
\text { software } \\
(9)\end{array}$ & $\begin{array}{l}\text { Decorati } \\
\text { on }(28)\end{array}$ & $\begin{array}{l}\text { Pharmac } \\
\text { euticals } \\
\text { (19) }\end{array}$ & $\begin{array}{l}\text { Trade } \\
(16)\end{array}$ & $\begin{array}{l}\text { Shops } \\
(35)\end{array}$ & $\begin{array}{l}\text { Hander } \\
\text { afts } \\
(36) \\
\end{array}$ & $\begin{array}{l}\text { Fashion } \\
\text { /design } \\
\text { (5) } \\
\end{array}$ & $\begin{array}{l}\text { Restaur } \\
\text { ants } \\
(20) \\
\end{array}$ & $\begin{array}{l}\text { Industri } \\
\text { es (14) }\end{array}$ & $\begin{array}{l}\text { Cut } \\
\text { flowers } \\
(13) \\
\end{array}$ & Tot-al & $100 \%$ \\
\hline $\begin{array}{l}\text { Deficiency of finance } \\
\text { access }\end{array}$ & 7 & 24 & 17 & 15 & 33 & 27 & 5 & 17 & 10 & 12 & 167 & $86 \%$ \\
\hline taxation & 6 & 13 & 8 & 12 & 26 & 9 & 2 & 7 & 12 & 10 & 105 & $54 \%$ \\
\hline $\begin{array}{l}\text { Lack of business } \\
\text { skills }\end{array}$ & 2 & 21 & 2 & 5 & 3 & 4 & 0 & 6 & 2 & 8 & 53 & $27 \%$ \\
\hline Low demands & 4 & 26 & 4 & 2 & 11 & 32 & 4 & 9 & 13 & 11 & 116 & $59 \%$ \\
\hline $\begin{array}{l}\text { Weak management } \\
\text { skills }\end{array}$ & 2 & 22 & 6 & 13 & 32 & 29 & 2 & 17 & 9 & 10 & 142 & $73 \%$ \\
\hline Lack of business plan & 3 & 24 & 5 & 14 & 30 & 25 & 0 & 16 & 3 & 9 & 129 & $66 \%$ \\
\hline $\begin{array}{l}\text { Insufficient trainings } \\
\text { and conferences }\end{array}$ & 7 & 20 & 17 & 16 & 34 & 16 & 4 & 5 & 9 & 6 & 134 & $69 \%$ \\
\hline $\begin{array}{l}\text { Lack of inputs and } \\
\text { raw materials }\end{array}$ & 2 & 28 & 17 & 8 & 5 & 32 & 5 & 1 & 14 & 11 & 123 & $63 \%$ \\
\hline High labor costs & 7 & 20 & 18 & 7 & 4 & 25 & 3 & 14 & 10 & 6 & 114 & $58 \%$ \\
\hline Lack of experience & 6 & 2 & 3 & 8 & 23 & 9 & 3 & 9 & 2 & 6 & 71 & $36 \%$ \\
\hline $\begin{array}{l}\text { Dispose of foreign } \\
\text { cheap products }\end{array}$ & 6 & 10 & 0 & 8 & 16 & 24 & 0 & 0 & 7 & 2 & 73 & $37 \%$ \\
\hline Marketing & 6 & 26 & 14 & 15 & 17 & 34 & 5 & 12 & 13 & 13 & 155 & $79 \%$ \\
\hline Competition & 8 & 25 & 6 & 14 & 20 & 31 & 3 & 9 & 9 & 11 & 136 & $70 \%$ \\
\hline
\end{tabular}

Source: Authors' field survey, 2019. 
The majority of selected SMEs run by women were affected by low access to finance (80\%); and most of them had the same challenge, that's why a Researcher has found more women started to work in groups as a cooperative to avoid this financial problem and they were able to receive credits from banks in easy way than one person. This system of grouping together is considered as a key access to accelerate a country economy development and improve life standards of Rwandans(Cheston \& Kuhn, 2002). Marketing of these SMEs run by women presents $79 \%$, weak management skills of $73 \%$, competition of $70 \%$ with the insufficient trainings and conferences of $69 \%$ which have been found during this research as one of the barriers to women who are doing business in Rwanda(Philip, 2011). Due to collected data, the interviewed women had different challenges in their businesses and the good thing from them was that they were not discouraged by them. The data suggests that if they should have enough supports from governments or non-government (NGOs), it will help them to improve their skills, financial status and their contribution rate in employment generation will be raise with their incomes as well.

The successful business should be multidimensional factors; either internal or external should have a good impact on success particularly in generating more employment opportunities to people. Moreover, SMEs run by women usually should compete according to its capacity and specialization. They should pay attention also to their ability of innovation in their work as one of the important factor to success.

Furthermore, the selected SMEs runs by women due to data received have been proved their contribution in generating employment opportunity. In Rwanda, females are the big number of the population, if they could dare and invest in business as men do, it will be greater outcome in reducing the high level of unemployment show up from case study. As we have seen in the previous notes, culture was a big barrier to women in many things, and we do believe that this research will help them (remain women) to brave or confident in doing business, to change their understandings which will increase their contribution in job creation, poverty reduction and gender equality as well. Generally, in developing countries women were used to be housewives and sometimes when their husbands are not around or died their families disturbed and others start doing prostitution because of the absence of their husbands, and so on. This research will remind them that apart from being housewives they can do more than that such as businesses.

\section{Conclusion and Recommendation}

Small and Medium Enterprises (SMEs) are key factors of employment generation, economic growth, and country development. Our study has focused on the contribution of SMEs run by women in generating employment opportunity in Rwanda.

We observed 10 selected sectors of SMEs run by women in Rwanda which had a clear contribution on employment generations with a positive influence on a country's economic growth and gender equality. The study discovered that as the number of SMEs run by women increased, the employment opportunities were also increased. According to our case study; the industries and handcrafts sectors have been recruited a significant number of people among others. 20 best businesswomen (Table.4) were a good example in spreading the spirit of business to other women, which gives us a hope to future Rwandans women entrepreneurship.

Finance is a crucial role in any business; SMEs run by women should be economically supported to be able to limit their challenges and lead them to recruit more employees. Through those given supports, People from the rural areas should be trained in various sectors of business like agro-industries to upgrade its rural welfare, reduce its poverty and unemployment as well.

The study has identified the contribution of SMEs run by women in Rwanda which were effectively great through their capacity in employment generation, gender equality, economic growth and country development. It recommended that the government may set policies to encourage women in doing business to different districts of Rwanda, and should be done due to their economic capacities. Arguably, their contributions will boost the rate of employment generation, and country development as well as its economy.

\section{Acknowledgments}

I would like first to express my deep appreciation to Prof' Hu Shengde, my research supervisor, to his enthusiastic encouragement, his patient, guidance and useful critiques on this research. I am very thankful for the assistance provided by colleagues was greatly appreciated. My special thanks to Rwanda Cooperative Agency, Rwanda Ministry of Trade and to all staffs for providing data.

I owe my thanks to a special person, my husband Assoumani KARINDA for his persist and unchanging love, understanding, and support during this research work that made it possible. Even if I felt to give up, he helped me to keep things in perspective; I greatly value his support and deeply appreciate. I would like to appreciate my 
little boy BINAMA Alvin Spencer for abiding my absence and ignorance and his patience during my research work. Words would never express how I am grateful to have both of you. I greatly appreciate my parents for encouragement and support during this research.

\section{References}

Aremu, M. A., \& Adeyemi, S. L. (2011). Small and medium scale enterprises as a survival strategy for employment generation in Nigeria. Journal of sustainable development, 4(1), 200. https://doi.org/10.5539/jsd.v4n1p200

Benería, L., Berik, G., \& Floro, M. (2015). Gender, development and globalization: Economics as if all people mattered. Routledge.

Cheston, S., \& Kuhn, L. (2002). Empowering women through microfinance. Draft, Opportunity International, 64.

Cochran, W. G. (1977). Sampling techniques-3. https://doi.org/10.2307/2347176

Corporation, I. F. (2008). Women Entrepreneurs in Rwanda. Retrieved from https://www.care.org.rw/resources/case-studies/item/317-women-entrepreneurs-in-rwanda

Dalitso, K., \& Peter, Q. (2000). The policy environment for promoting small and medium-sized enterprises in Ghana and Malawi. University of Manchester.

Etuk, R. U., Etuk, G. R., \& Michael, B. (2014). Small and medium scale enterprises (SMEs) and Nigeria's economic development. Mediterranean Journal of Social Sciences, 5(7), 656. https://doi.org/10.5901/mjss.2014.v5n7p656

Francis, H. (2019). Combating Fungal Diseases in Rwandan Agriculture. Retrieved 24th June, 2019, from https://www.icco-cooperation.org/en/newsarticle/combating-fungal-diseases-in-rwandan-agriculture

Huggins, A., \& Randell, S. K. (2007). Gender equality in education in Rwanda: What is happening to our girls. Paper presented at the South African Association of Women Graduates Conference. South Africa: Cape Town.

Hussain, A. (2013). E-COMMERCE AND BEYOND opportunities for developing country SMEs. Paper presented at the International Trade Forum.

Izabiliza, J. (2003). The role of women in reconstruction: Experience of Rwanda. Source unknown.

Kira, A. R., \& He, Z. (2012). The impact of firm characteristics in access of financing by small and medium-sized enterprises in Tanzania. International Journal of Business and Management, 7(24), 108. https://doi.org/10.5539/ijbm.v7n24p108

Lacs, P. G. (2015). Rwanda concerned over Lack of investors in Flower Industry. Retrieved 12-08-2019, from https://www.infosgrandslacs.info/productions/rwanda-concerned-over-lack-investors-flower-industry

Leedom, S. (2016). A look at four promising SMEs in Rwanda (Online Database). Retrieved 20 June, 2019, from https://www.howwemadeitinafrica.com/look-four-promising-smes-rwanda/54362/

Löfström, Å. (2009). Gender equality, economic growth and employment. Swedish Ministry of Integration and Gender Equality.

MANDEYA, M. (2019). The Inspirational Women Behind Rwanda's Homegrown Fashion Trends. Retrieved 12th August, 2019, from https://weekender.rw/2019/06/04/the-inspirational-women-behind-rwandas-homegrown-fashion-trends/

Marlow, S., \& Patton, D. (2005). All credit to men? Entrepreneurship, finance, and gender. Entrepreneurship theory and practice, 29(6), 717-735. https://doi.org/10.1111/j.1540-6520.2005.00105.x

Murangwa, Y. (2017). The Establishment Census 2017. Rwanda: National Institute of Statistics of Rwanda (NISR). Retrieved from http://www.statistics.gov.rw/datasource/establishment-census-2017

Mutandwa, E., Taremwa, N. K., \& Tubanambazi, T. (2015). Determinants of business performance of small and medium size enterprises in Rwanda. Journal of Developmental Entrepreneurship, 20(01), 1550001. https://doi.org/10.1142/S1084946715500016

Philip, M. (2011). Factors affecting business success of small \& medium enterprises (SMEs). Amity Global Business Review, 6(1), 118-136.

Reporter, T. (2011). Rwandan handicrafts unique. 
Seawright, J., \& Gerring, J. (2008). Case selection techniques in case study research: A menu of qualitative and quantitative options. Political Research Quarterly, 61(2), 294-308. https://doi.org/10.1177/1065912907313077

Tambunan, T. (2008). SME development, economic growth, and government intervention in a developing country: The Indonesian story. Journal of international entrepreneurship, 6(4), 147-167. https://doi.org/10.1007/s10843-008-0025-7

Twahirwa, A. (2014). Tech Entrepreneur Encourages Rwanda's Young Women to Venture into ICT. Retrieved 08-08-2019, from https://ourworld.unu.edu/en/tech-entrepreneur-encourages-rwandas-young-women-to-venture-into-ict

Vis, C. (2012). Educating women entrepreneurs in Kigali, Rwanda. Unpublished Master's thesis, University of Amsterdam, Amsterdam.

$\begin{array}{lllll}\text { Worldometer. } & \text { (2019). } & \text { Rwanda } & \text { Population. }\end{array}$ https:/www.worldometers.info/world-population/rwanda-population/

\section{Notes}

Note 1. SMEs: Small and Medium Enterprises.

Note 2. Z-score determined based on Confidence level which is the probability that the value of a parameter falls within a specified range of values.

Note 3. Margin of Error is a small amount that is allowed for in case of miscalculation or change of circumstances (generally equal to $5 \%=0.05$ )

Note 4. This is a result on our calculation on sample size for infinite population.

Note 5. The adjusted sample size was our used sample size (195).

\section{Abbreviations}

SMEs: Small and Medium Enterprises.

GDP: Gross Domestic Product.

ICT: Information and communications technology.

SPSS: Statistical Package for the Social Sciences (also known as IBM SPSS Statistics).

SM: Sonia Mugabo.

NBG: National Bank of Georgia.

NGO: Non Governmental Organization.

\section{Copyrights}

Copyright for this article is retained by the author(s), with first publication rights granted to the journal.

This is an open-access article distributed under the terms and conditions of the Creative Commons Attribution license (http://creativecommons.org/licenses/by/4.0/). 